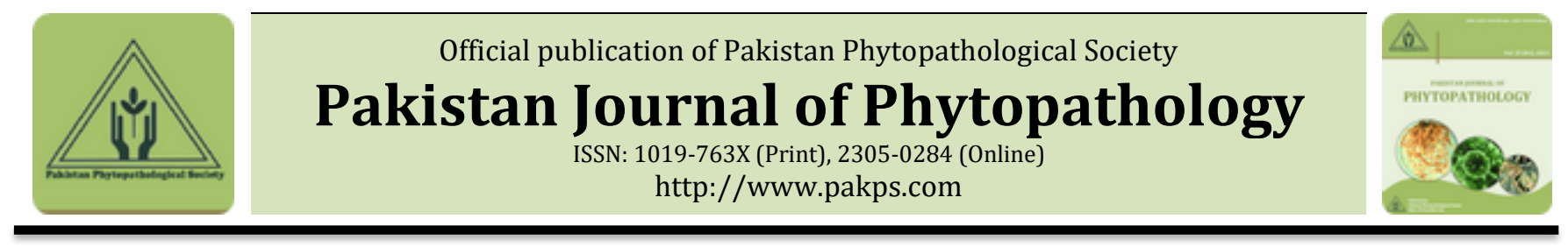

\title{
CITRUS TRISTEZA VIRUS IN PAKISTAN: A REVIEW
}

\author{
aSagheer Atta*, bMaroof Sidique, cSidra Ashiq, dAbdul Hannan \\ ${ }^{a}$ Departmet of Plant Protection, Faculty of Agricultural Sciences, Ghazi University Dera Ghazi Khan, Pakistan. \\ bInstitute of Agricultural Sciences, University of the Punjab, Lahore, Pakistan. \\ 'Department of Horticulture, Faculty of Agricultural Sciences, Ghazi University Dera Ghazi Khan, Pakistan. \\ Department of Botany, Ghazi University Dera Ghazi Khan, Pakistan.
}

\begin{abstract}
A B S T RA CT
Citrus is one of the most widely grown fruit crop in the world. Citrus tristeza virus (CTV) is one of the most economically important viral pathogen of citrus and causes different disease syndromes. The use of infected bud wood and aphids are the main cause of spread of CTV. The virus is genetically diverse and causes various symptoms like slow and quick decline, stunting, stem pitting, vein clearing and seedling yellows. Strategies have been developed to reduce the economic losses caused by CTV. Quarantine measures, bud wood certification, mild strain cross protection and eradication programs are some of the strategies that can prevent the spread of this disease. New approaches are provided by advancement in genetic engineering and molecular biology. Transgenic plants have been developed to provide resistance against the disease.
\end{abstract}

Keywords: Citrus tristeza virus; infected bud wood; aphids; stem-pitting; Mild Strain Cross Protection

\section{INTRODUCTION}

Citrus is one of the major fruit that is grown in Pakistan as well as in the world. In Pakistan, it is grown on an area of 199,000 hectares and shares approximately $40 \%$ of the fruit produced in Pakistan (Atif et al. 2015).

Citrus tristeza virus (CTV), an important pathogen of citrus, considered as one of the most damaging diseases of citrus (Bar-Joseph and Lee, 1989; Lee and Bar-Joseph, 2000). It belongs to the family Closteroviridae in genus Closterovirus. It has caused destruction of millions of citrus trees throughout the world (Moreno et al. 2008; Bar-Joseph et al. 1979). The use of infected bud wood and aphids are mainly responsible for the spread of disease. Toxoptera citricidus (brown citrus aphids) and Aphis gossypii (cotton aphid) are the vectors involved in the transmission of the disease. All the citrus species, cultivars and hybrids are susceptible to Citrus tristeza virus (CTV) and induce severe symptoms. Sweet orange

Submitted: April, 25, 2017

Revised: July, 12, 2017

Accepted for Publication: July, 31, 2017

* Corresponding Author:

Email: satta@gudgk.edu.pk

(C) 2017 Pak. J. Phytopathol. All rights reserved. and other varieties that are grafted on rootstock of sour orange are also infected. Grapefruit, lemon and lime are also susceptible.

Significance: In Spanish, "Tristeza" means "sadness or melancholy", and it has caused huge losses in many countries while the word tristeza refers to various disease symptoms. CTV has been declared one of the most economically important viral pathogen of citrus among all the known virus and virus like diseases of citrus (Lee and Joseph, 2000). Over a 100 million trees have been affected by CTV quick decline around different countries and regions of the world viz: Argentina, Brazil, California, Spain, Asian countries, and other areas (Roistacher, 1992).

Two types of CTV mainly affect citrus production:

(a) Quick decline and necrosis of phloem cells below the bud union of trees on lemon, sour orange and grapefruit rootstocks.

(b) In many cultivars, regardless of the rootstock, severe stem pitting symptoms and tree decline have been observed ultimately resulting in low yield and poor fruit quality (Roistacher, 1992; Mehta, et al. 1997).

In early 20th century, in South Africa and in 1930's in Argentina, Brazil and Argentina, the epidemics of citrus 
caused by CTV were first reported on sour orange (Moreno et al. 2008; Rocha Penna et al. 1995). More than 10 million trees in Argentina, 6 million in Brazil and 3 million trees in USA were lost due to decline caused by CTV (Bar-Joseph et al. 1989). It is also stated that in 1975 in Spain the first outbreak of CTV disease was reported, 40 million trees of mandarin (C. reticulate) and sweet oranges $(C$. sinensis) that were grafted on sour orange $(C$. aurantium) rootstock have declined (Cambra et al. 2000).

Pathogen: Citrus tristeza virus

Taxonomy:

\begin{tabular}{|c|c|}
\hline \multicolumn{2}{|c|}{ Classification } \\
\hline Genome & (+) ss RNA \\
\hline Family & Closteroviridae \\
\hline Genus & Closterovirus \\
\hline Species & Citrus tristeza virus \\
\hline Synonyms & $\begin{array}{l}\text { Grapevine A virus; Citrus quick decline } \\
\text { virus (Fawcett and Wallace 1946); Lime } \\
\text { dieback Closterovirus; Hassaku dwarf } \\
\text { virus }\end{array}$ \\
\hline
\end{tabular}

Biology of Pathogen: Virions of Citrus tristeza virus (CTV) are flexuous, have size of about $2000 \times 11 \mathrm{~nm}$ and a $20 \mathrm{~kb}$ single-stranded, positive sense genomic RNA. It comprises of 12 open reading frames (ORFs) which encodes for at least 17 different protein products and at the $5^{\prime}$ and $3^{\prime}$ termini. It has two un-translated regions (UTRs) of about 107 and 273 nt (Karasev et al. 1995; Mawassi et al. 1996; Yang et al. 1999; Vives et al. 1999). In CTV, two genes encode two different proteins, a major coat protein (CP) of $25 \mathrm{kDa}$ and a minor coat protein $(\mathrm{CPm})$ that is of $27 \mathrm{kDa}$. These proteins are encoded by ORF 7 and 8 and about $97 \%$ and $3 \%$ of the virion length is encapsidated by them respectively (Febres et al.1996; Satyanarayana et al. 2004).

Vector and Budwood Transmission of Pathogen: As seed transmission does not occur we have to suppose an early adaptation of CTV by aphid transmission. Aphids are the main source of disease spread in the field. Four aphid species (Aphis gossypii, the cotton or melon aphid; $A$. spiraecola, the spirea aphid; Toxoptera aurantii, the black citrus aphid; and Toxoptera citricida, the brown citrus aphid) have been associated with the natural transmission of CTV (Rocha-Peña, et al. 1995). Toxoptera citricida is worldwide in its distribution, present in all the citrus growing areas and considered as the most potent vector among these aphids (Rocha-Pena et al. 1995; Yokomi et al. 1994; Lee, 2000). Aphids transmit pathogen in a semipersistent manner (Moreno et al. 2008). Many isolates of CTV are effectively transmitted by $T$. citricida at efficient transmission rate of $80-100 \%$ (Yokomi et al. 1994). In
Pakistan, cotton aphid A. gossypii is the efficient vector of CTV (Bove, 1995).

Propagation of virus-infected buds is the cause of dispersal of CTV into new areas, while the aphid vector is responsible for local spread. Host range, distribution and the efficiency of transmission vary among these aphids (Rocha-Pena et al. 1995). The virus has also been experimentally transmitted to healthy plants by dodder (Cuscuta subinclusa) and by stem-slash inoculation with partially purified extracts (Garnsey et al. 1987) but these procedures are epidemiologically unimportant.

CTV Host Range: Genus citrus is the natural host of CTV, and most of the species and hybrids of this genus are infected by the virus (Muller and garnsey, 1984). Some species were considered as natural host of CTV as given by Brunt (Brunt et al. 1996).

- Citrus spp. grafted onto sour orange (C. aurantifolia).

- Grapefruit (C. paradise)

- Lime (C. aurantifolia)

- Seville orange (C. aurantium)

- Mandarin (C. reticulate)

- Afraegle paniculata, Aeglopsis chevalieri, Pamburus missionis

Disease Development: The disease is prevailing in all the citrus growing areas of Pakistan (Atta et al. 2012) and the virus persists in aphids that are vectors of CTV. In all the varieties of citrus, disease development is prevailing on rootstocks and bud stocks. In an experiment, colonies of $A$. gossypii were reared on healthy seedlings of sour orange and then placed on CTV infected sweet orange and allowed to feed on it for 24 hours (Rahimian et al. 2000). Then the aphids were inoculated on 6-8 leaf seedling stage of Mexican lime (C. aurantilolia) for another $24 \mathrm{hrs.} \mathrm{In} \mathrm{four}$ out of eight recipient lime seedlings, after a period of 45 days of feeding, symptoms like vein clearing and cupping appeared on the newly expanding leaves. A. gossypii cause severe epidemics with disease incidence of $11 \%$ in 1989 that increases to 53\% in 1998 (Cambra et al. 2000).

Signs and Symptoms: The symptoms shown by Citrus Tristeza closterovirus vary according to combination of the scion rootstock and the strain of the virus. There is great genetic and biological diversity in the virus therefore it causes a number of various symptoms including stunting (Fig. 1), slow decline (Fig. 2), quick decline (Fig. 3), seedling yellow, vein clearing (Fig. 4) and stem pitting (Fig. 5) or it may show no symptoms depending upon different isolates of virus, root stock, 
cultivar, time of infection and the environmental conditions.

Decline of trees is one of the most significant symptoms of the tristeza disease. It includes leaf chlorosis and dieback of the infested portions of tree. Decline may either be slow or quick depending upon the strain of the virus. In case of slow decline, the process may last for months to years after the symptoms are noticed. A bulge is also seen on the infected tree above the bud union. This type of decline is accompanied by loss in productivity. Infected tree does not die in this case. In case of quick decline, death of the infected tree occurs just after few months of symptom appearance (Brunt et al. 1996). Quick decline results in girdling of the rootstock, depleting the starch reserves and force the tree to starve to death.

Another common symptom is stunting where the tree is generally not killed by the virus strain, but the growth of the tree is affected showing a stunted growth. Vein clearing is also observed in the leaves of citrus infected by different strains of CTV. The veins appeared to become lighter in color making the surrounding lamina more prominent and darker in color.

Stem-pitting is another common symptom of CTV that establishes in most host types and in citrus trees grafted onto sour orange rootstock. Pits are developed in the trunk and stem of the infected trees, resulting in decreased tree vigor and reduced fruit yield. Stem pitting is typically caused by the more virulent strains of CTV. The severity of the symptoms depends on the species of citrus and the strain of the Tristeza virus.

Uneconomical citrus production due to less vigor and small sized fruit are caused by stem pitting isolates and many citrus trees on sour orange or on related rootstock are killed by the decline isolates of the virus (Miyakawa, 1987; Garnsey et al. 1987).

A number of complex syndromes are caused by Citrus tristeza virus (CTV) in citrus spp. and of these syndromes two most important are decline and stem pitting. Decline was observed on the trees that were propagated on sour orange ( $C$. aurantium) rootstock, and in susceptible scions despite of using resistant rootstock, stem pitting symptoms appeared in decline tolerant cultivars (Lee, 2000; karasev, 2000). CTV infected citrus trees usually have small leaves, often produce small sized fruits and show dieback of twigs. Trees that are affected by stem pitting have low yield, poor growth, and produce small fruits. Stem pitting symptoms are most common on lime (C. aurantifolia) and grapefruit (C. paradise), cut symptoms can also be observed on sweet oranges $(C$. sinensis) (Lee et al. 2002).

Type of scion variety and rootstock have influence on the appearance of symptoms in grown up citrus groves and these may vary from grove to grove. Affected leaves become chlorotic showing different shades and often curl upward and lengthwise. Roots are severely injured in trees affected by CTV.

The symptoms caused by virus are mostly related to different strains like decline, stem pitting, vein clearing, lef corking and stunting and also to the rootstock and scion combination (Lbida 2005).

Epidemiology: Citrus tristeza virus can cause infection only when virus is transmitted to the phloem sieve tubes. The infection caused by the virus is limited to only few of the phloem cells in each phloem bundle. This allows other strains of the virus to cause infection in rest of the phloem cells of the same plant by multiplying there. The cells that are adjacent to the sieve tube began to degenerate and cells become necrotic after infection.

The formation of normal xylem and phloem is inhibited when the degeneration spreads to the cambium in those plants that develop stem pitting. A pit is left in the wood when the bark is removed because the tissue that is produced in the lesion is soft and is disorganized and remains attached to the bark. In some roots feeder roots are totally damaged after infection rather than in localized areas and as a result to this infection no normal xylem or phloem is produced.

In those hosts that are affected by seedling yellows, the cells adjacent to phloem sieve tubes are subjected to degeneration. Leaves and stems are only slightly affected by this, but feeder roots are highly affected and become necrotic. Feeder roots are entirely deteriorated after the infection of cambium and improper phloem formation (Agrios, 1991).

Tristeza disease is transmitted by grafting and some vectors. It is a disease of citrus trees grafted on sour orange rootstock and caused by a virus. In various combinations of scion and rootstocks, the tristeza symptoms that appeared are not due to the susceptibility of the host but are due to the harmful effects of the virus on the cells of the phloem in rootstock just below the union.

Management: Huge economic losses are caused by CTV. In order to minimize the losses caused by CTV, a number of control strategies have been developed. On the basis of absence or presence of CTV, these strategies are available 
in different citrus growing areas (Bar-Joseph and Lee, 1989; Lee and Rocha-Pena, 1992). These strategies include quarantine measures and eradication programs to prevent the spread of the virus, certification of bud wood to prevent the introduction of CTV, the use of mild strain cross protection (MSCP), use of CTV-tolerant rootstocks, breeding for CTV resistance, and genetic engineering (Bar-Joseph and Lee, 1989; Lee and RochaPena, 1992).

If a plant is previously affected by a mild strain of the virus it can be protected from infection caused by more severe strains of virus, this phenomenon is called cross protection (Fulton, 1986). Before evaluation of CTV isolates, different temperature regimes and conditions of field site need to be tested for mild strains (Powell et al. 1992). In countries such as Australia, Brazil, South Africa, India and Japan, Mild Strain Cross Protection (MSCP) has been applied as management strategies (Rocha-Pena et al. 1995). In South Africa, grapefruit production would be uneconomic without the use of CTV cross-protection due to CTV stem-pitting causing strain (Von Broembsen and Lee, 1988; Van Vuuren et al. 1993; Van Vuuren and da Graça, 2000). The breakdown of cross protection in Florida has provided the evidence that cross protection is only efficient against the stem pitting disease but has not proved to be efficient against quick decline disease (Lee et al. 1996).

Genetic Engineering for CTV Resistance: New approaches and research in genetic engineering and molecular biology have provided new opportunities for the generation and evaluation of transgenic plants for resistance against viruses outside of conventional breeding methods (Cevik, 2001). With the help of genetic engineering, new genes are inserted into already present cultivars and desirable and beneficial traits are added without altering cultivar integrity. Genetic engineering has made scientists capable of developing such varieties that have either host or pathogen-derived resistance against infection caused by CTV. Resistance against viruses has been developed in several plants by transforming these plants with genes or sequences from other sources (Fuchs and Gonsalves, 1997).

Status of CTV in Pakistan: A little work is available on CTV in Pakistan as the disease has received very little attention. Citrus plantation has shorter life in Pakistan that ends in deterioration of fruit quality, lower yield and early demise of tress. In Punjab and NWFP different virus and virus like diseases of citrus were surveyed. The presence of Citrus tristeza closterovirus (CTV) in citrus trees was confirmed with the help of electron microscopy, enzyme-linked immune sorbent assay (ELISA) technique (Catara et al. 1989); Anwar \& Mirza; 1992) and by RT-PCR (Atta et al. 2011). A survey was carried out and more than fifty orchards and ten nurseries were sampled in different areas of the Punjab. ELISA tests and EM observations showed that CTV was present in the varieties in different districts. Mosambi was the most affected variety among the mosambi, bloodred and pineapple sweet orange (Catara et al. 1991). Anwar and Mirza (1992) conducted a survey in 14 localities and in five districts viz. Sahiwal, Sargodha, Faisalabad, Lahore and Sheikhupora and confirmed the prevalence of CTV by ELISA test with the highest infection (18.8\%) in Sahiwal, followed by Sargodha (13.20\%) and Faisalabad (13.13\%), while no infection was found in Lahore district. In NWFP, symptoms of vein clearing and chlorosis were observed in young leaves of $C$. aurantium, C. limon cv. Eureka and $C$. sinensis by grafting and mechanical inoculation (Arif et al. 2005). Extensive surveys of the major citrus groves in Punjab and N.W.F.P and ELISA tests showed that the CTV incidence in Bhalwal and the Punjab were $44.61 \%$ and $48.46 \%$, and in Mardan and N.W.F.P were $37.39 \%$ and $40.86 \%$ respectively in 2006-2007 and increased in 2009-2011 making sweet oranges infection up to 50\% (Iftikhar et al. 2009). In 2012, CTV isolates were graft inoculated for Mild Strain Cross Protection (MSCP) evaluation studies and sequenced (under press).

Different strategies are used to control CTV in different areas depending upon the severity and incidence of strain and type of cultivar and root stock used. Single control strategy cannot be used for the control of CTV that will be applicable in all the situations (Garnsey et al. 2005). CTV tolerant rootstocks are used to control the losses induced by CTV. A certification program in which bud wood source trees are tested and maintained free of CTV can be used as the most effective mean of limiting CTV-induced diseases (Garnsey et al. 2005).

The shoot-tip micro grafting is known technique that is used for the elimination of virus and viroid pathogens from citrus germplasm. Quarantine and certification programs generally apply this technique using small trees maintained under glass or screen houses (Krueger et al. 2003). The micro grafting technique was successfully applied for the elimination of CTV in mandarins and sweet oranges. This technique was successfully and efficiently used for elimination of different viruses from 
citrus species (Murashige et al. 1972; Navarro et al. 1975; Naz et al.2007).

\section{CONCLUSION AND FUTURE CHALLENGES}

Although 80 years of CTV epidemic have passed since its first infection, tristeza epidemic is increasing in many regions of the world, including Pakistan. Tristeza decline may cause more losses in future and even destroy the citrus industry of some countries. Dispersal of tristeza induced diseases in Pakistan have vanished out sweet orange cultivars and is increasing very rapidly, which may lead to the destruction of the citrus industry of the country as well as that of the neighboring countries. While some management strategies may eventually tackle the problem and restore the citrus production, such as replacement of declining trees with new trees having tristeza tolerant rootstocks, resistance genes, cross protection and identification of pathogenicity determinants for different disease syndromes. Citrus production can be increased through nurseries running on a scientific and professional basis. Certified citrus nurseries are needed to solve the problem caused by CTV. Better understanding of the relationship among CTV isolates, host plants and vectors should be strengthened, which has been absolutely limited in Pakistan. The combination of using certified budwood programs plus MSCP strategy is certainly the best way to control the losses induced by CTV.

\section{REFRENCES}

Agrios, C. N. 1991. Plant Pathology. Academic Press INCL, New York.

Anwar, S. and S. Mirza. 1992. Survey of Citrus Tristeza Virus in Punjab. Proceedings 1st International Seminar on Citriculture in Pakistan. pp. 413-416.

Arif, M., A. Ahmed, M. Ibrahim and S. Hassan. 2005. Occurence and Distribution of Virus and Virus Like Diseases Of Citrus in North West Frontier Province of Pakistan. Pakistan Journal of Botany, 37: 407421.

Atif, M., Z. Hassan and S. Ahmed. 2015. Pakistan's Citrus industry: (An overview of key constraints). The Patriot, 01.

Atta, S., Y. Liu, M. Cao, F.-Y. Yang, Y. Zhou and C. Zhou. 2011. Molecular characterization of Citrus Tristeza Virus isolates from Pakistan based on CPG/Hinf I restriction fragment length polymorphism (RFLP) groups analysis. African Journal of Biotechnology, 10: 8689-8694.

Atta, S., C.-y. ZHOU, Z. Yan, M.-j. CAO and X.-f. WANG. 2012.
Distribution and research advances of Citrus Tristeza Virus. Journal of Integrative Agriculture, 11: 346-358.

Bar-Joseph, M., S. Garnsey and D. Gonsalves. 1979. The closteroviruses: a distinct group of elongated plant viruses. Advances in virus research, 25: 93-168.

Bar-Joseph, M. and R. Lee. 1989. Citrus Tristeza Virus. AAB Descriptions of plant viruses, 353.

Bar-Joseph, M., R. Marcus and R. F. Lee. 1989. The continuous challenge of Citrus Tristeza Virus control. Annual Review of Phytopathology, 27: 291-316.

Bove, J. M. 1995. Virus and virus-like diseases of citrus in the Near East region.

Brunt, A. 1996. Plant Viruses Online: Descriptions and Lists from the VIDE Database. Ver. 20. http://biology. anu. edu. au/Groups/MES/vide/.

Cambra, M., M. T. Gorris, C. Marroquin, M. P. Román, A. Olmos, M. C. Martınez, A. H. de Mendoza, A. Lopez and L. Navarro. 2000. Incidence and epidemiology of Citrus Tristeza Virus in the Valencian Community of Spain. Virus Research, 71: 85-95.

Catara, A., A. Azzaro, M. Davino, V. Grimaldi, M. Hussain, M. Saleem and M. Mirza. 1991. A survey of tristeza and greening in Punjab, Pakistan. Proceedings of 11th Conference of the International Organization of Citrus Virologist. Riverside, University of California. pp. 166-170.

Catara, A., A. Azzaro, S. Mughal and D. Khan. 1988. Virus, viroid and prokaryotic diseases of citrus in Pakistan. Proceedings of 6th Conference of the International Organization of Citrus Virologist. Tel Aviv. pp. 957-962.

Çevik, B. 2001. Characterization of the RNA-dependent RNA polymerase gene of citrus tristeza closterovirus. University of Florida.

Febres, V., L. Ashoulin, M. Mawassi, A. Frank, M. BarJoseph, K. Manjunath, R. Lee and C. Niblett. 1996. The p27 protein is present at one end of Citrus Tristeza Virus particles. Phytopathology, 86: 13311335.

Fuchus, M. and D. Gonsalves. 1997. Environmently safe approaches to crop disease control in Genetic Engineering. CRC Press: 333-368.

Fulton, R. W. 1986. Practices and precautions in the use of cross protection for plant virus disease control. Annual review of Phytopathology, 24: 67-81.

Garnsey, M., G. SM, C. CN, L. EL and Y. RF. 1987. Toward a 
standardized evaluation of the biological properties of Citrus Tristeza Virus. Phytophylactica, 19: 151-158.

Garnsey, S. M. and L. W. Timmer. 2000. Compendium of citrus diseases. Minnesota, US: APS Press, 1988.

Iftikhar, Y., M. A. Khan, A. Rashid, S. Mughal, Z. Iqbal, A. Batool, M. Abbas, M. Khan, S. Muhammad and M. Jaskani. 2009. Occurrence and distribution of Citrus Tristeza Closterovirus in the Punjab and NWFP, Pakistan. Pakistan Journal of Botany, 41: 373-380.

Karasev, A., V. Boyko, S. Gowda, O. Nikolaeva, M. Hilf, E. Koonin, C. Niblett, K. Cline, D. Gump and R. Lee. 1995. Complete sequence of the Citrus Tristeza Virus RNA genome. Virology, 208: 511-520.

Karasev, A. V. 2000. Genetic Diversity and Evolution of colesteroviruses. Phytopathology, 38: 293-324.

Krueger, R., T. Kahn, D. Gumpf, P. Balance, O. Bier and J. Bash. 2003. Shoot-tip micro grafting for rescue or therapy of field-grown citrus germplasm accessions. Proceedings 9th ISC Congress.

Lbida, B., A. Bennani, M. Serrhini and M. Zemzami. 2005. Biological, serological and molecular characterization of three isolates of Citrus tristeza closterovirus introduced into Morocco. EPPO bulletin, 35: 511-517.

Lee, R. F., H. R. Pappu, S. S. Pappu, M. A. Rocha-Pena, V. J. Feberes, K. L. Mnjunath, O. V. Nikolaeve, A. karasev, B. Cevik, M. Akbulutt, D. Bencher, E. J. Anderson, M. Price, F. M. Ochoa-Corona and C. J. Nibblet. 1996. Progess on strain differentiation of Citrus Tristeza Virus. Phytopathology, 14: 79-87.

Mawassi, M., E. Mietkiewska, R. Gofman, G. Yang and M. Bar-Joseph. 1996. Unusual sequence relationships between two isolates of Citrus Tristeza Virus. Journal of General Virology, 77: 2359-2364.

Mehta, P., R. Brlansky, S. Gowda and R. Yokomi. 1997. Reverse-transcription polymerase chain reaction detection of Citrus Tristeza Virus in aphids. Plant Disease, 81: 1066-1069.

Miyakawa, T. 1987. Strains of Citrus Tristeza Virus in Japan. Phytophylactica, 19: 139-144.

Moreno, P., S. Ambros, M. R. Albiach-Marti, J. Guerri and L. Pena. 2008. Citrus Tristeza Virus: A pathogen that changed the cause of citrus industry. Molecular Plant Pathology, 9: 251-268.

Murashige, T., W. Bitters, T. Rangan, E. Nauer, C. Roistacher and P. Holliday. 1972. technique of shoot apex grafting and its utilization towards recovering virus-free Citrus clones. HortScience.

Navarro, L., C. Roistacher and T. Murashige. 1975. Improvement of shoot-tip graftingin vitro for virus-free citrus. Journal of the American Society for Horticultural Science, 100: 471-479.

Naz, A. A., M. J. Jaskani, H. Abbas and M. Qasim. 2007. In vitro studies on micrografting technique in two cultivars of citrus to produce virus free plants. Pak. J. Bot, 39: 1773-1778.

Powell, C., R. Pelosi and M. Cohen. 1992. Superinfection of orange trees containing mild isolates of Citrus Tristeza Virus with severe Florida isolates of Citrus Tristeza Virus. Plant Disease.

Rahimian, H., V. Alavi, J. Shayegan and A. Hadizadeh. 2000. Spread of Citrus Tristeza Virus by Aphis gossypii in the North of Iran. Iranian Journal of Plant Pathology, 36.

Rocha-Peña, M. A., R. F. Lee, R. Lastra, C. Niblett, F. M. Ochoa-Corona, S. M. Garnsey and R. K. Yokomi. 1995. Citrus Tristeza Virus and its aphid vector Toxoptera citricida: threats to citrus production in the Caribbean and Central and North America. Plant Disease, 79: 437-445.

Roistacher, C. 1992. Should we introduce protective isolates of Citrus Tristeza Virus. Citrograph, 77: 5-9.

Satyanarayana, T., S. Gowda, M. A. Ayllón and W. O. Dawson. 2004. Closterovirus bipolar virion: evidence for initiation of assembly by minor coat protein and its restriction to the genomic RNA 5' region. Proceedings of the National Academy of Sciences of the United States of America, 101: 799804.

Shepherd, R. J. 1977. Intrinsic properties and taxonomy of aphid-borne viruses, Aphids as Virus Vectors. Elsevier, pp. 121-136.

Van Vuuren, S., R. Collins and J. Da Graça. 1993. Evaluation of Citrus Tristeza Virus isolates for cross protection of grapefruit in South Africa. Plant Disease, 77: 2428.

Van Vuuren, S. and J. Da Graca. 2000. Evaluation of grafttransmissible isolates from dwarfed citrus trees as dwarfing agents. Plant disease, 84: 239-242.

Vives, M., L. Rubio, J. Navas-Castillo, M. Albiach-Mart, W. Dawson, J. Guerri, R. Flores and P. Moreno. 1999. The complete genome sequence of the major component of a mild Citrus Tristeza Virus isolate. Journal of General Virology, 80: 811-816. 
Von Broembsen, L. and A. Lee. 1988. South Africa's citrus improvement programme. International Organization of Citrus Virologists Conference Proceedings (1957-2010).

Yang, Z.-N., D. M. Mathews, J. A. Dodds and T. E. Mirkov. 1999. Molecular characterization of an isolate of Citrus Tristeza Virus that causes severe symptoms in sweet orange. Virus Genes, 19: 131-
142.

Yokomi, R., R. Lastra, M. B. Stoetzel, V. Damsteegt, R. Lee, S. Garnsey, T. Gottwald, M. Rocha-Peña and C. Niblett. 1994. Establishment of the brown citrus aphid (Homoptera: Aphididae) in Central America and the Caribbean Basin and transmission of Citrus Tristeza Virus. Journal of Economic Entomology, 87: 1078-1085. 